\title{
Original
}

\section{THE MODE OF INHIBITING ACTION OF Ca/P RATIO IN A CARIES-INDUCING DIET, 6PMV, IN RATS***}

\author{
Masao ONISI* and Fumiko OZAKI**
}

\begin{abstract}
Of three caries inhibiting factors, $\mathrm{Ca}, \mathrm{P}$, and $\mathrm{Ca} / \mathrm{P}$ ratio, in caries inducing diets recommended by different authors, $\mathrm{C} / \mathrm{P}$ ratio functioned as the primary determinant. It is considered that $\mathrm{Ca}$-and $\mathrm{P}$-conponents could form a cubic concave surface mode of action against caries incidence, and the proposed model reconciled the previous arguments on this subject.
\end{abstract}

Koy words: Ca/P ratio, Rat, Experimental caries, Diet

\section{Introduction}

The caries preventing effect of $\mathrm{Ca}$ and $\mathrm{P}$, which almost all diets contain in various ratios, has been so conflictingly reported by different authors that one group ascribes the caries reducing activity to $\mathrm{Ca}^{1,2)}, \mathrm{a}$ second to phosphates ${ }^{8,4)}$, and a third to the $\mathrm{Ca}: \mathrm{P}$ ratio $^{5)}$.

$\mathrm{McClur}^{6)}$ and Dalderup") claimed that no caries reduction was caused by increasing $\mathrm{Ca}$ in the diet which they used. Nizel and Harris") reviewed papers published until 1962, emphasizing the P effect, even when it was influenced by the kind of phosphate and the way of administration, and they stressed the im-

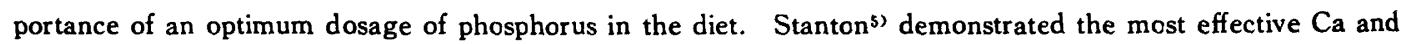
$P$ ratio to be 0.55 to 0.65 for average American adults by analysis of the foods which they ate in one week. $\mathrm{McClure}$ and $\mathrm{McCamm}^{8)}$, however, found that changing the $\mathrm{Ca} / \mathrm{P}$ ratio of the diet not influence caries susceptibility in rats when they were placed on a caries-inducing diet after weaning. Sobel et $\mathrm{a}^{\left.{ }^{3}\right)}$ stressed the good effect of $P$ in the diets designed with several $\mathrm{Ca} / \mathrm{P}$ ratios. Wynn et $\mathrm{a}^{9-11}$ concluded from serial studies that a larger amount of $\mathrm{Ca}$ and $\mathrm{P}$ in diets with a constant $\mathrm{Ca} / \mathrm{P}$ ratio of 1.0 resulted in a laryger reduction of caries incidence.

However, we ${ }^{12)}$ obtained results similar to those of Stanton in a diet containing a modified McCollum salt mixture by which we were able to obtain various $\mathrm{Ca} / \mathrm{P}$ ratios by replacing $\mathrm{CaCO}_{3}$ with $\mathrm{NaHCO}$.

The objective of the present studies, therefore, was to reconcile the incompatible claims presented by the different authors working with the $\mathrm{Ca}$ and $\mathrm{P}$ problem in caries-inducing diets and to represent the mode of action of these diets.

\section{Material and Methods}

From the pure strain colony of Wistar rats kept at the Department of Preventive Dentistry, Tokyo Medical and Dental University, Faculty of Dentistry, 180 rats 21 days old were divided into 9 groups contain. ing 20 rats each. 4 groups were used for the lst experiment testing the effect of a Ca-constant-but-P-variable

* Present Address : Department of Oral Bacteriology, Faculty of Dentistry, Showa University

** Department of Preventive Dentistry and Public Health, Faculty of Dentistry, Tokyo Medical and Dental University

*** The major parts of this Paper were read before the 21st (1972) and the 23rd (1974) Annual meetings, Japanease Society for Dental Health

* 現住所：炤和大学齿学部口腔細菌学教空

**東京医科歯科大学齿学部予防啮科学教室 眧和59年 1 月 20 日受付 
Table 1 Components of 6PMV.

\begin{tabular}{|c|c|}
\hline Sugar & $600 \mathrm{~g}$ \\
\hline$\alpha$-Starch & $210 \mathrm{~g}$ \\
\hline Casein & $100 \mathrm{~g}$ \\
\hline Salt mixture* & $50 \mathrm{~g}$ \\
\hline Panvitan & $10 \mathrm{~g}$ \\
\hline Olive oil & $30 \mathrm{ml}$ \\
\hline \multicolumn{2}{|c|}{ * Modified McCollum's salt mixture } \\
\hline $\mathrm{CaCO}_{8}$ & $544.08 \mathrm{~g}$ \\
\hline $\mathrm{KH}_{2} \mathrm{PO}$ & $212.00 \mathrm{~g}$ \\
\hline $\mathrm{KCl}$ & $112.00 \mathrm{~g}$ \\
\hline $\mathrm{NaCl}$ & $69.00 \mathrm{~g}$ \\
\hline $\mathrm{MgSO}_{4} \cdot 7 \mathrm{H}_{2} \mathrm{O}$ & $32.80 \mathrm{~g}$ \\
\hline $\mathrm{MgCO}_{8}$ & $25.00 \mathrm{~g}$ \\
\hline $\mathrm{MnSO}_{4} \cdot 4 \mathrm{H}_{2} \mathrm{O}$ & $51.00 \mathrm{~g}$ \\
\hline $\mathrm{FePO}_{4} \cdot 4 \mathrm{H}_{2} \mathrm{O}$ & $20.50 \mathrm{~g}$ \\
\hline $\mathrm{CuSO}_{4} \cdot 5 \mathrm{HO}_{2}$ & $1.46 \mathrm{~g}$ \\
\hline $\mathrm{Al}\left(\mathrm{SO}_{4}\right)_{3} \cdot \mathrm{K}_{2} \mathrm{SO}_{4} \cdot 24 \mathrm{H}_{2} \mathrm{O}$ & $0.31 \mathrm{~g}$ \\
\hline
\end{tabular}

salt mixture in the caries inducing diet, $6 \mathrm{PMV}^{13)}$, and 5 groups were used for the 2 nd experiment to test the effect of $\mathrm{Ca}$ and $\mathrm{P}$ in the same diet system. Modification of $\mathrm{Ca}$ and $\mathrm{P}$ content was done by changing the amount of $\mathrm{CaCO}_{3}$ and/or $\mathrm{KH}_{2} \mathrm{PO}_{4}$ in the McCollum salt mixture in the 6PMV. The actual amounts of $\mathrm{Ca}$ and $\mathrm{P}$ are found in Table 2 for the lst experiment and in Table 3 for the 2 nd experiment. All rats freely drunk the deionized water provided.

At the end of 30 days caries time, they were decapitated under choloroform anesthesia, and the jaws were placed in $10 \%$ neutral formalin solution for the fixation. Later, three molars from one side, usually the right side, were sawed into three serial sections about $100 \mu \mathrm{m}$ thick with a Bronwill's apparatus.

Table 2 Caries production on a Ca-constant-but-P-variable diet during the 30 days caries time.

\begin{tabular}{ccccccccc}
\hline $\begin{array}{c}\text { Rats } \\
\text { groups }\end{array}$ & \multicolumn{2}{c}{ Diet system } & $\mathrm{Ca} / \mathrm{P}$ & \multicolumn{2}{c}{ No. of rats } & \multicolumn{2}{c}{ Body weight } & \multicolumn{2}{c}{$\begin{array}{c}\text { Caries production } \\
\text { surviving }\end{array}$} & $\mathrm{Wo}(\mathrm{g})$ & $\Delta \mathrm{W}(\mathrm{g})$ & \multicolumn{2}{c}{$\begin{array}{l}\text { Prevalence } \\
\text { (Frequency) Extent }\end{array}$} \\
\hline 1 & 12.01 & 10.20 & 1.2 & 18 & 36.2 & 56.9 & 0.50 & 1.22 \\
2 & 12.01 & 8.70 & 1.4 & 19 & 37.4 & 49.8 & 0.44 & 1.11 \\
3 & 12.01 & 6.45 & 1.9 & 18 & 37.3 & 49.0 & 0.42 & 1.17 \\
4 & 12.01 & 4.25 & 2.8 & 18 & 35.9 & 44.2 & 0.61 & 1.56 \\
\hline
\end{tabular}

Wo: Body weight at the beginning of the experiment.

$\Delta \mathrm{W}$ : Body weight gain during the caries time.

Table 3 Caries production on a $\mathrm{Ca}$ - and $\mathrm{P}$-variable diet during the 30 days caries time.

\begin{tabular}{cccccccccc}
\hline $\begin{array}{c}\text { Rats } \\
\text { groups }\end{array}$ & \multicolumn{2}{c}{$\begin{array}{c}\text { Diet system } \\
\mathrm{Ca}(\mathrm{g} / \mathrm{K})\end{array}$} & $\mathrm{P}(\mathrm{g} / \mathrm{K})$ & $\mathrm{Ca} / \mathrm{P}$ & $\begin{array}{c}\text { No of rats } \\
\text { surviving }\end{array}$ & \multicolumn{2}{c}{ Body weight } & \multicolumn{3}{c}{ Caries production } \\
$\mathrm{Wo}(\mathrm{g})$ & $\Delta \mathrm{W}(\mathrm{g})$ & $\begin{array}{c}\text { Prevalence } \\
\text { (Frequency) }\end{array}$ & Extent \\
\hline 5 & 29.58 & 19.40 & 1.5 & 18 & 34.1 & 26.4 & 0.22 & 0.44 \\
6 & 16.38 & 8.14 & 2.0 & 20 & 34.3 & 45.9 & 0.30 & 0.45 \\
7 & 13.08 & 5.29 & 2.4 & 18 & 33.7 & 41.5 & 0.50 & 1.00 \\
8 & 11.88 & 4.33 & 2.7 & 19 & 34.4 & 35.3 & 0.74 & 2.34 \\
9 & 10.80 & 3.40 & 3.2 & 19 & 34.2 & 32.4 & 0.88 & 4.53 \\
\hline
\end{tabular}

Induced lesions were detected on a film shadowed by soft X-Ray under a low power microscope. The lesions, which were usually found at the dento-enamel junctions under the bottom of the fissures and on the contact areas were scored and averaged, giving the caries extent of the group. The carious rate of the surviving rats of the group was also counted as the caries inducing capacity of the diet, giving the caries prevalence of the group. The prevalence of the group is convertible to the logarithm of the extent 
based on the fact: $P=0.625 \log E+0.512^{14}$, where $P$ represents the prevalence and $E$ represents the extent.

\section{Results}

The Findings are shown in Tables 2 and 3 and plotted in Figure 1, where the $\mathrm{Ca} / \mathrm{P}$ is plotted on the abscissa and caries prevalence and extent are plotted on the ordinate.

In the lst $P$-variable-but-Ca-constant diet experiment, the caries incidence curve reached the lowest point, showing the most effective dose of phosphorus against the constant $\mathrm{Ca}$ amount in the diet. In the 2nd $\mathrm{Ca}$-and-P-variable diet experiment, caries incidence was decreased by increasing both $\mathrm{Ca}$ and $\mathrm{P}$ in the diet, suggesting that the minimum point was approached.

\section{Disucssion}

To reach an undisputed conclusion from the data obtained, it is necessary to consider the quantitative relations of $\mathrm{Ca}, \mathrm{P}$, and $\mathrm{Ca} / \mathrm{P}$ ratio at the minimum point of caries incidence. It would be reasonable to combine the data obtained in our previous work on Ca-variable-but-P-constant conversion of the 6PMV, even though the caries lesions developed in this case were evaluated by counting open cavities on each fissures after 90 days of caries time, as shown in Table 4 and Figure 1.

Table 4 Cavity production on a Ca-variable-but-P-constant diet during 90 days caries time.*

\begin{tabular}{cccccccccc}
\hline $\begin{array}{c}\text { Rats } \\
\text { group }\end{array}$ & \multicolumn{2}{c}{ Diet system } & $\mathrm{Ca}(\mathrm{g} / \mathrm{K})$ & $\mathrm{P}(\mathrm{g} / \mathrm{K})$ & $\mathrm{Ca} / \mathrm{P}$ & $\begin{array}{c}\text { No. of rats } \\
\text { surviving }\end{array}$ & \multicolumn{2}{c}{ Body weight } & \multicolumn{2}{c}{ Cavity production } \\
& & & $\mathrm{Wo}(\mathrm{g})$ & $\Delta \mathrm{W}(\mathrm{g})$ & $\begin{array}{c}\text { Prevalence } \\
\text { (Frequency) }\end{array}$ & Extent \\
\hline 1 & 1.67 & 3.45 & 0.48 & 30 & 34.5 & 182 & 0.30 & 0.7 \\
2 & 3.34 & 3.45 & 0.96 & 24 & 35.7 & 190 & 0.08 & 0.3 \\
3 & 6.70 & 3.45 & 1.94 & 30 & 35.0 & 169 & 0.00 & 0.0 \\
4 & 10.88 & 3.45 & 3.15 & 28 & 35.8 & 148 & 0.36 & 1.4 \\
\hline
\end{tabular}

* All data are reproduced from results obtained in a previous experiement. ${ }^{12}$

As Tables 2, 3, and 4 show, the actual concentrations of $\mathrm{Ca}$ and $\mathrm{P}$ at the least caries incidences are scattered widely the most effectve $\mathrm{Ca}$ concentration was $29.6 \mathrm{~g} / \mathrm{k}$ diet in the $2 \mathrm{nd}$ experiment and $6.7 \mathrm{~g} / \mathrm{k}$ diet in the previous experiment, the most effective concentration of $P$ was $6.45 \mathrm{~g} / \mathrm{k}$ diet in the 1 st experiment and $19.4 \mathrm{~g} / \mathrm{k}$ diet in the 2 nd experiment. Considering the counter minerals contained in the same diets, however, the wide variability of the $\mathrm{Ca}$ and $\mathrm{P}$ content in the diet meets in the narrow range of $\mathrm{Ca} / \mathrm{P}$ ratios $1.4-1.9$. These results, therefore, indicate that the $\mathrm{Ca} / \mathrm{P}$ ratio is the primary determinant in all diets.

The above discussion can be expressed by a cubic concave image, in other words, a valley-shaped surface constructed from three axis of the caries incidence, Ca-content, and P-content of a diet (Fig. 2).

The caries incidences obtained from previous data on a Ca-variable diet, however, have to be enlarged to compare them to the caries incidences obtained in the present experiments, because open cavities are much less estimable than the closed early lesions found in the dentinoenamel junction of the molars detectable on microradiograms ${ }^{15)}$. If the above presumptions are accepted, the cubic concave mode of action expresses the findings of all the various authors cited in the introductory paragraph of this paper.

However, further discussion is needed on the discrepancy found between our most effective $\mathrm{Ca} / \mathrm{P}$ ratio (1.4-1.9) and Stanton's (0.55 to 0.65). This could be explained by the differences in test objects (rats vs. human adults) and different of approaches (synthetic diet vs. reports on food consumed for one week). Based on the proposed model, speaking in general, in order to decrease caries incidence in both countries, it is 


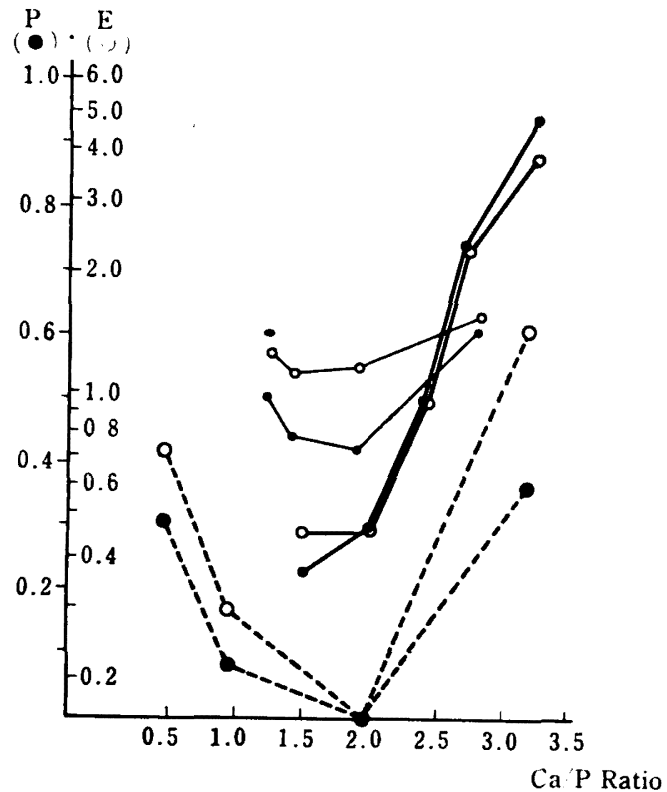

Figure 1 Interrelationships between produced caries and $\mathrm{Ca} / \mathrm{P}$ ratios in three experiments.

- and $O$ denote data from Ca-constant-but-P-variable diet, $\odot$ and $O$ data from $\mathrm{Ca}$-and $\mathrm{P}$-variableliet, and $O$ and $O$ data from $\mathrm{Ca}$-variable-butP-constant diet

$P$ : Prevalence of caries

E : Extent of caries

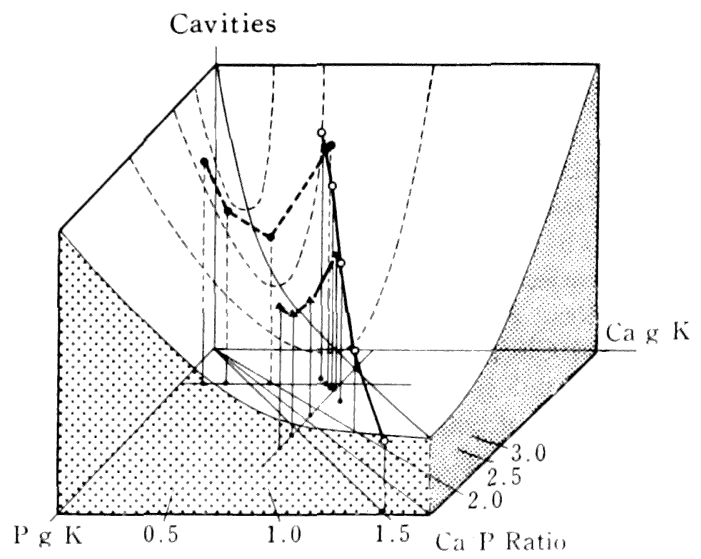

Figure 2 The proposed model of caries inhibiting mode of action between $\mathrm{Ca} / \mathrm{P}$ ratio, $\mathrm{Ca}$ and $\mathrm{P}$ amount, and caries incidence.

$\mathrm{CI}$ axis: Caries incidence represented by caries prevalence.

$\mathrm{Ca}$ axis : $\mathrm{Ca}$ content in $\mathrm{g} / \mathrm{kilogram}$ diet.

$P$ axis: Phosphorous content in $g /$ kilogram diet.

A : Ca-constant,but-P-variable diet.

$\mathrm{O}$ : Ca-and P-variable diet.

- : Ca-variable-but-P-constant diet.

necessary eat more Ca-containing foods in Japan, where the diet is low in $\mathrm{Ca}\left(\mathrm{Ca} / \mathrm{P} 0.31\right.$ in $\left.1963^{16)}\right)$, and Stantion suggested need of additional phosphorus in U. S. foods.

\section{Acknowledgement}

We express our appreciation to Mrs. Yoshiko Chikaraishi and Miss Bunjo Ryo for their tireless laboratory assistance.

\section{Reference}

1) Constant, M. A., Sivert, H. W., Phillips, P. H. and Elvehjem, C. A.: Dental caries in the cotton rat. IV. Further studies of caries production by natural diets with especial refference to the role of minerals, fat, and the stage of refinement of cerials, J. Nutrition, 53 ; 17-27, 1954.

2) Constant, M. A., Sivert, H. W., Phillips, P. H. and Elvehjem, C. A.: Dental caries in the cotton rat. XV. The effect of tooth maturity and minerals on caries production by semi-synthetic diet, J. Nutrition, $53 ; 29$ 41, 1954.

3) Sobel, A. E., Shaw, J. H. and Hanok, A : Calcification. XXVI. Caries susceptibility in relation to composition of teeth and diet, J. D. Res., 39 ; 462-472, 1960.

4) Nizel, A. E. and Harris, R. S. : The effect of phosphates on experimental dental caries : A lierature review, J. D. Res., 43 supple; 1123-1136, 1964.

5) Stanton, G. : Diet and dental caries. The 
phosphate sequestration hypothesis, N. Y. State D. J., 35 ; 399-407, 1969.

6) McClure, F. J.: Wheat cereal diets, rat caries, lysine and minerals, J. Nutrition, 65 ; 619-631, 1958.

7) Dalderup, L. M. : Nutrition and caries. IX. The influence of calcium carbonate on rat caries induced by a cariogenic diet, J. D. Res., 38 ; 1173-1177, 1959.

8) McClure, F. J. and McCamm, H. G. : Dental caries and composition of bones and teeth of white rats. Effect of dietary mineral suppliments, Arch. Oral Biol., 2 ; 151-161, 1960.

9) Wynn, W, Haldi, J., Bentley, K. D. and Law, M. L.: Dental caries in the albino rat in relation to the chemical composition of the teeth and of the diet. II. Variation in the $\mathrm{Ca} / \mathrm{P}$ ratio of the diet induced by changing the phosphorus content, J. Nutrition, 58; 325-333, 1956.

10) Haldi, J., Wynn, W., Bentley, K. D. and Law, M. L. : Dental caries in the albino rat in relation to the chemical composition of the teeth and of the diet. IV. Variation in the $\mathrm{Ca} / \mathrm{P}$ ratio of the diet induced by changing the calcium content, J. Nutrition, 67 ; 645-653, 1959.
11) Wynn, W., Haldi, J. and Law, M. L. : Dental caries in albino rat fed diets containing different ammount of calcium and phosphorus with the same $\mathrm{Ca} / \mathrm{P}$ ratio, J. D. Res., 39 ; 1248-1252, 1960.

12) Onisi, M. and Ozaki, F.: Prevention of experimental rat caries. VI. Prevalence-Extent relationship in experimental fissure in rat, J. Dent. Helth., 19 ; 71-83, 1969.

13) Onisi, M., Ozaki, F., Mimura, T., Ogura, H. and Tamaoki, S. : Prevention of experimental rat caries. I. Tooth marking by EDTA-Pb for the experimental caries study in Wistar rats, J. Dent. Helth., 15 ; 145148, 1955.

14) Onisi, M., Ozaki, F., Hirayama, Y. and Ryo, B. : Additional findings on the early lession and correction of Prevalence-Extent formula of the rat caries, J. Dent. Helth., $26 ; 100$, 1976.

15) Onisi, M., Ozaki, F. and Okano, M.: Prevention of experimental rat caries. IV. Two different lesions in dentin appeared on the fissure caries of rats, J. Dent. Helth., 18 ; 39-53, 1968.

16) Dental Helth Section, Dept. Med. Affair, Min. Helth and Welfare: Data relating on Dental Health, 1964.

檄要 : 鼠のう蝕話発食佴, $6 \mathrm{PMV}$ 中の $\mathrm{Ca} / \mathrm{P}$ 比率のう蚛阻止作用様式, 大西正男*, 尾䗁文子**

食眲に含まれている $\mathrm{Ca}, \mathrm{P}$ とその $\mathrm{Ca} / \mathrm{P}$ 比率のいうれが，鼠う䖵誘発能力揤制するかを知るため に, 合成う強筧食眲 $6 \mathrm{PMV}$ の Ca と P 成分を変えることによって, Wistar 系瓦に発生するう蝕数 の変化を観察した。その結果う触抑制の第一次決定因子は, $\mathrm{Ca} / \mathrm{P}$ 比率であることがわかった。食饵中

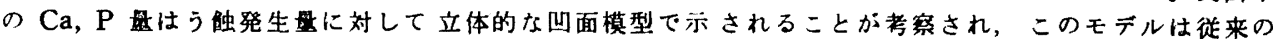
この問題に対する 3 つ学説を統一した。

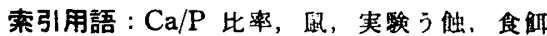

